\title{
How do red deer react to increased visitor numbers? A case study on human-deer encounter probability and its effect on cortisol stress responses
}

\author{
Gabriel Dixon', Andrew S. Marriott', Graham Stelfox', \\ Chris Dunkerley², Sven P. Batke'
}

I Edge Hill University, Ormskirk, UK 2 National Trust, Stockport, UK

Corresponding author: Gabriel Dixon (dixong@edgehill.ac.uk)

Academic editor: J. Tzanopoulos | Received 7 July 2020 | Accepted 24 December 2020 | Published 26 February 2021

http://zoobank.org/C74DAEA8-C67E-4964-81A3-BED1C5C7C25F

Citation: Dixon G, Marriott AS, Stelfox G, Dunkerley C, Batke SP (2021) How do red deer react to increased visitor numbers? A case study on human-deer encounter probability and its effect on cortisol stress responses. Nature Conservation 43: 55-78. https://doi.org/10.3897/natureconservation.43.56266

\begin{abstract}
The numbers of visitors to greenspaces in the United Kingdom has increased over the last few years as the health benefits of spending time in greenspaces have become better known. This has led to problems for conservation ecologists due to increased numbers of reported human-wildlife encounters. Deer are often found in public spaces and are of particular concern. Previous research suggests elevated levels of stress hormones (e.g., cortisol) in deer is a result of increased human activity. This has been linked to several negative effects on the deer's health. From a practitioner's point of view, it is therefore important to implement effective management strategies that are based on scientific evidence to help ensure the welfare of managed deer populations. In an effort to identify the impact of visitor numbers on faecal cortisol concentrations, samples from 2 red deer (Cervus elaphus) herds in Lyme Park (Cheshire), United Kingdom, were collected and analysed. A predictive spatial model was developed based on logistic regression to identify areas within the park of low and high human-deer encounter probability. The faecal cortisol levels were found to be significantly higher on days with a high number of visitors. In addition, landscape features such as buildings and roads increased the probability of human-deer encounters, whereas woodland and scrub decreased the probability. However, human-deer encounter probability changed with distance to the features. By providing local park managers with this scientific data, these findings can directly inform current management efforts to reduce deer stress levels in Lyme Park. In addition, the spatial modelling method has the capacity to be implemented in other parks across the country with minimal cost and effort.
\end{abstract}

Copyright Gabriel Dixon et al.. This is an open access article distributed under the terms of the Creative Commons Attribution License (CC BY 4.0), which permits unrestricted use, distribution, and reproduction in any medium, provided the original author and source are credited. 


\section{Keywords}

Assay, Cervus elaphus, cortisol, modelling, red deer, visitors

\section{Introduction}

A Natural England report found that over a seven-year period there has been a $4 \%$ increase in the number of adults visiting a greenspace at least once a week; up to 28 million people or 58\% of England's adult population (Natural England 2011; Natural England 2017). Recreational use of green spaces has been promoted due to the physical and mental health benefits it offers such as lowering rates of depression, anxiety, and high blood pressure (Sandifer et al. 2015; Shanahan et al. 2016; Cox et al. 2017), as well as reducing brain activity in areas linked to increased mental illness risk (Bratman et al. 2015). The importance of these health-related services has been identified in UK policy, which highlights them as vital components of nature conservation (DEFRA 2011). This has resulted in the proportion of health motivated visits to nature rising from approximately a $1 / 3$ ( 0.97 billion) of all visits in 2009-2010, to approximately $1 / 2$ ( 1.51 billion) of all visits in 2015-2016 in England (Natural England 2011; Natural England 2017).

This increase in visitors has led to problems for conservation ecologists, as intensity of visitors to a habitat has been found to negatively impact various different organisms, most notably by directing their habitat selection to areas which are less desirable. The richness and distribution of plants were found to be reduced in highly visited areas (Jägerbrand and Alatalo 2015; Malavasi et al. 2016); invertebrates, such as Bathyporeia pelagica, have found to be absent from their preferred and expected habitat solely due to trampling resulting from human activity (Reyes-Martínez et al. 2015). Both birds (Thiel et al. 2008; Coppes et al. 2017b, D’Acunto et al. 2018). Mammals were also found to avoid areas with high human activities which may prevent them from utilising their optimal habitat (Haigh et al. 2017; Reilly et al. 2017.) Deer are a common parkland species in the UK, found in over 90 public accessible parks across Britain (British Deer Society 2018). Previous studies have investigated the differing impacts of human activity on deer habitat usage (George and Crooks 2006; Sibbald et al. 2011; Bonnot et al. 2013; Scholten et al. 2018), diet composition (Jayakody et al. 2011) and behavioural responses (Reimoser 2012). Each of these impacts were found to be linked to human-induced stress.

Deer stress is an important management consideration as it is a contributing factor for the general welfare of a herd. When stressed, the ability of the deer to react quickly to changes in their environment is hampered and how the deer react to these changes may be altered (Broom 1991). These altered reactions as a response to stress could be behavioural: for example, a stressed deer being more likely to respond aggressively to additional stressors, such as a visitor or dog who gets too close - an issue for parkland sites where the safety of visitors is under constant scrutiny (Hubbard and Nielson 2009). The reaction could also be physiological, with higher stress levels being 
linked to a decrease in immune system function, reproduction and metabolic processes (Cherry et al. 2016; Sapolsky et al. 2000).

Site managers are faced with the challenges of mitigating negative impacts to their deer populations; this includes the growing issue of rising human utilisation of these greenspaces. This study was carried out in response to this challenge and it was hoped that the work we carried out could help to bridge the gap between understanding the impact of human activity on deer stress, and the predicted occurrence of stress events across a landscape. The results of this study were readily applicable to the herds of red deer (Cervus elaphus) at a specific site, Lyme Park in Cheshire, UK. The methods and findings of this study can then be used to inform management in a broader context and can be utilised at other similar sites. Thus, the main aims of this study were to (a) explore whether an increase in stress hormones can be attributed to increased visitor numbers, and to (b) inform the current management practices through the development of a spatial model that can predict the chance of a human-deer encounter occurring. Throughout this paper the term human-deer encounter probability will be used to describe the likelihood of human activity occurring within close proximity to the deer.

\section{Study area}

The study was conducted at Lyme Park, Disley, Cheshire, United Kingdom (53.338041, -2.0547761). The site covers approximately 590 hectares; the native, wild red deer were enclosed in the park during the $14^{\text {th }}$ century. The site is a large natural area just outside of Greater Manchester and is popular with visitors from this built-up urban area, and from further afield. Lyme Park is open to visitors around the year. The site vegetation is predominantly grassland, but the park also contains a range of habitats typical of Northern England (Fig. 1). Grazing by sheep (Ovis aries), highland cattle (Bos taurus) and red deer occurred throughout the park with the objective of promoting plant diversity. Prior to 2002 deer were able to graze in the whole park until they were fenced out of a central zone (Fig. 2) due to concerns that increasing visitor numbers would generate greater disturbance for the deer. When the deer were excluded from the central zone they were separated into two herds: one herd was located closer to the main visitor attractions of the park (the "Park Herd") and the other was in the less visited moorland area (the "Moor Herd"). During study period the Park Herd consisted of approximately 160 animals, and the Moor Herd of approximately 90 animals (Fig. 2).

Over the last 5 years the number of visitors to Lyme Park has risen by approximately 150,000 individuals based on the number of vehicles entering the site. The number of total visitors in 2018 is likely closer to 750,000 when accounting for visitors taking public transport to the site, or walking into the park through alternate entrances (National Trust 2018a, b). The site is well developed for tourism and is visited all year round; a large number of these visitors are brought to the park to see its historical features. These features include the $16^{\text {th }}$ century mansion house and associated gardens, a hunting lodge named "the cage" and the deer park (and by extension the deer) itself. Aside from tourists, the site is frequently visited by local walkers, families and hikers. 


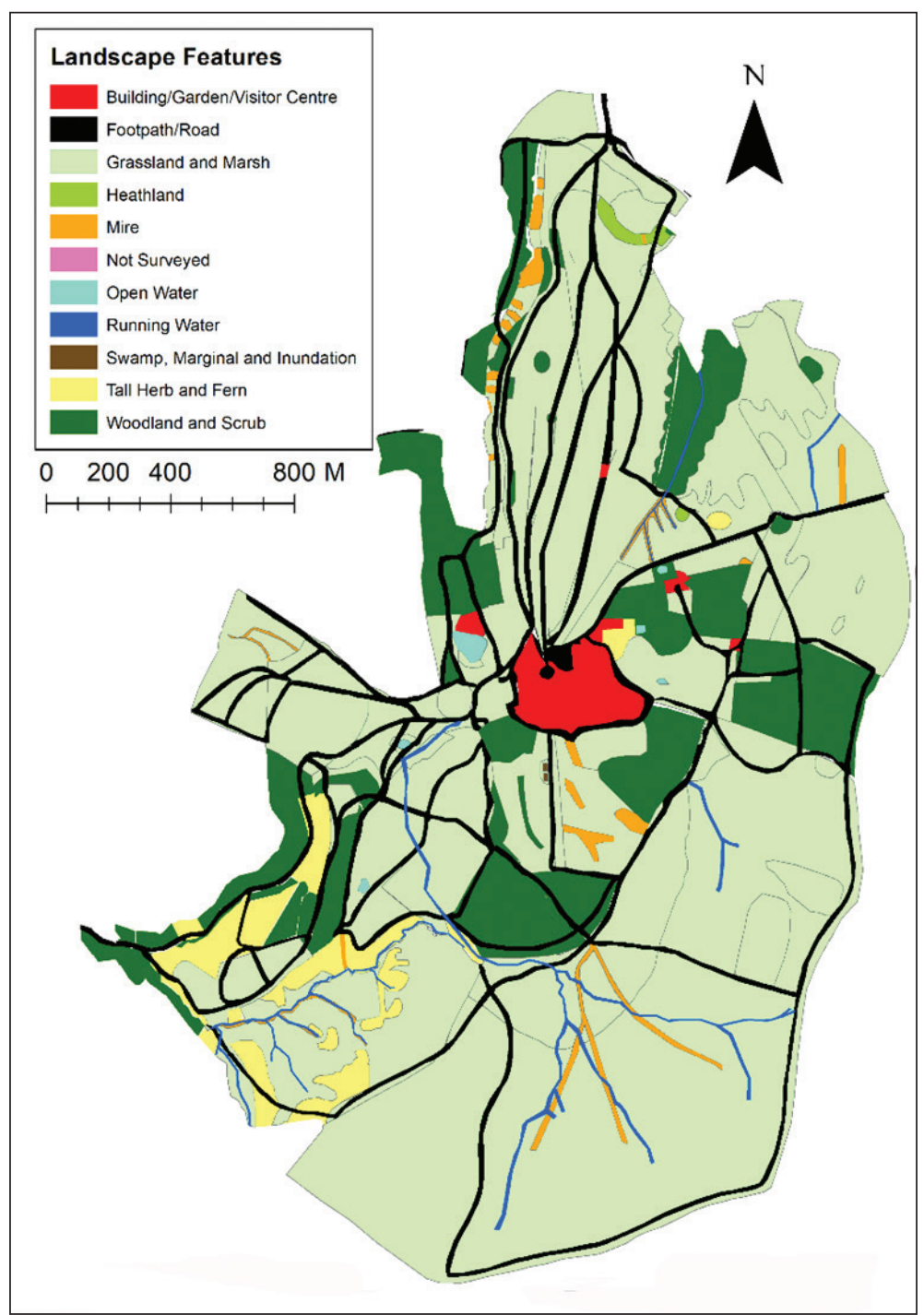

Figure I. Map of landscape features. Each landscape feature is shown as a different colour. Data collected from Lyme Park, Disley, UK, in 2018.

\section{Methods}

\section{Identifying areas of shared habitat use and landscape features}

The experienced park ranger team, made up of four rangers, work in the park every day of the week for nine hours per day. During the study the rangers had 20 years of experience visually tracking the movements of the deer daily throughout the year to carry out management tasks such as feeding and culling the herds. Attention is paid to which areas of the park the deer use to ensure that the management of the habitat 


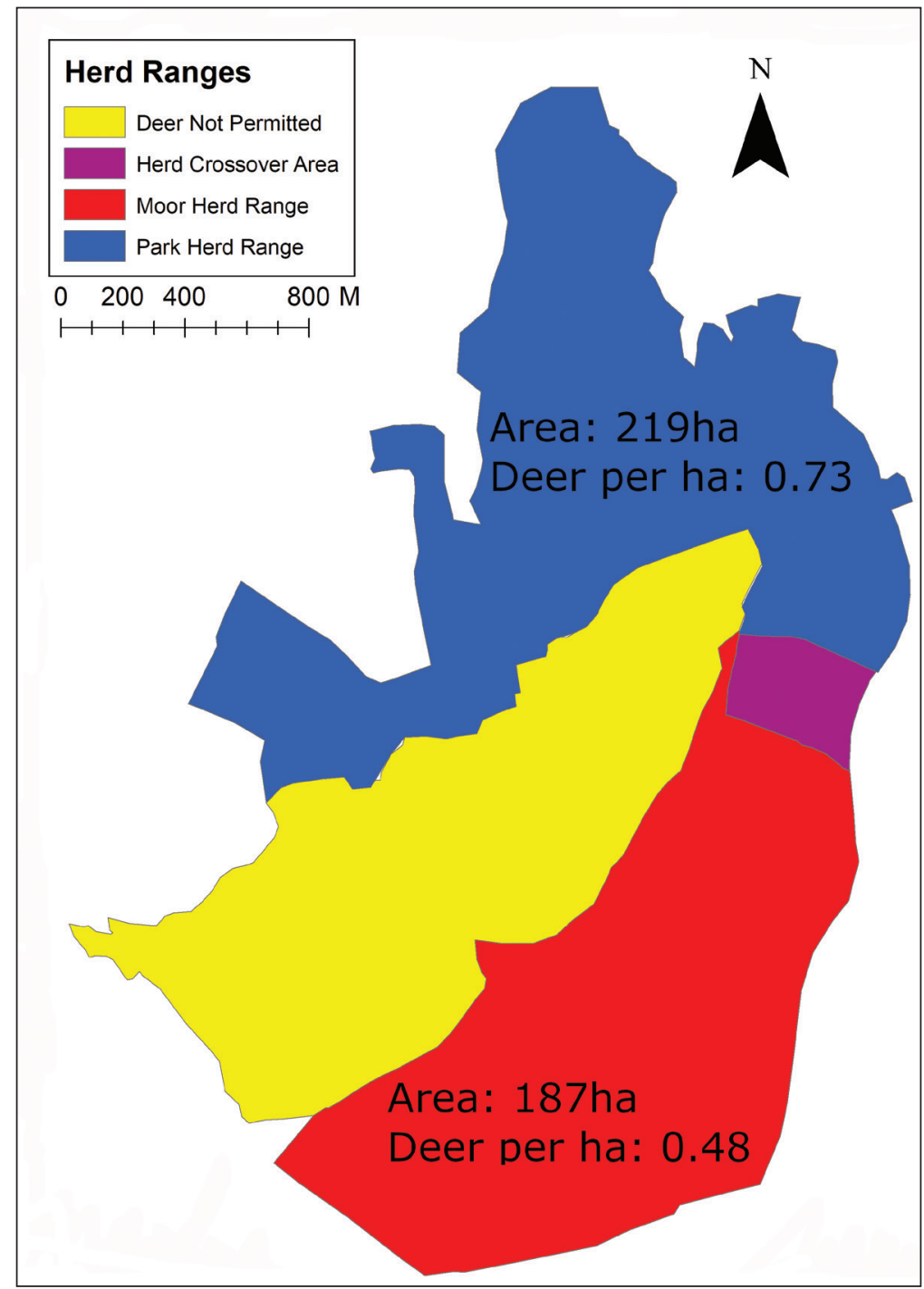

Figure 2. Map showing the area open to each of the herds. The herd crossover area (area accessible to both herds) is included in the total area of both herds. Area where deer are excluded also shown. Data collected from Lyme Park, Disley, UK, in 2018.

is well informed. We used these historic space-use observations to compile and create two qualitative maps; one which displayed the areas of the park which were heavily utilised by the two herds of deer and one which displayed the areas of the park most heavily utilised by the human visitors. To ensure that the deer and visitor movements were accurately represented by these maps, observations were visually confirmed by the authors over approximately 100 hours between June and August in 2018. This was done by counting the number of visitors and deer in each area of the park for a mini- 
mum of three hours per day, four days a week over the seven-week study period. This method was chosen because observational data is usually the only data available to park managers, due to the high costs and specialised knowledge required to install GPS tags. Although GPS tracking data would have been desirable, we were not given permission to tag the deer during the period the study took place. Similarly, our activity data for visitors relied on observational accounts of the park managers and on visual confirmation of these accounts by the authors of this study.

The two sets of activity data, human and deer, were used to create two maps; these maps split the park into areas of high activity (where the visitors/deer were most often found) and areas of low activity (areas where visitors/deer rarely visited). The two separate activity maps were overlaid to identify the areas of the park which are shared and utilised by both the deer herds and human visitors; these areas were categorised as areas of "High likelihood of encounter". Conversely, the areas where deer and human usage did not overlap were categorised as areas of "Low likelihood of encounter" (Fig. 3).

Geographical landscape feature information was obtained from the National Trust as a shapefile (National Trust 2018c). The footpaths and roads were digitised and added to the maps manually using ArcGIS (2011) and the highest resolution aerials images available. There was a total of nine landscape features, which could affect the likelihood of human-deer encounters, identified (Table 1). The area covered by each landscape feature within each of the herds' range is presented in Table 2.

\section{Generating distance matrix data}

To create a dataset from which encounter probability could be modelled, information provided by two maps were used to generate a distance matrix. Two hundred random points were selected from both the low and high encounter zones (Fig. 3) using the ArcGIS (Environmental Systems Research Institute, Inc., Redlands, CA, USA) 'Create Random Points' tool from the 'Sampling Toolset'. This resulted in 5,494,400 probability calculations, which was also the maximum number of calculations that we were able to run on our computer systems. No points were selected from the deer exclusion zone in the park (Fig. 3).

The distance matrix required the landscape feature shapefile to be converted into a raster file; this conversion was carried out using ArcGIS and resulted in the map being divided into $20 \times 20 \mathrm{~m}$ grid cells. Each cell was assigned a landscape cover feature (Table 1), based on the highest proportion of each feature in a cell. Cells containing footpaths or roads were prioritised during this assignment, as they are important access routes for visitors. This was necessary due to the long, narrow nature of footpaths and roads, resulting in a low relative area within each of the grid cells. In the case of running water, we did not prioritise this feature during our assignment because it was mainly located in areas that visitors did not utilise and because the few small streams that were in the study area, were mostly seasonal.

The distance matrix calculated the distance from each selected low and high-risk points (Fig. 3) to each separate landscape feature in the raster file using the Point Distance' tool in ArcGIS. 


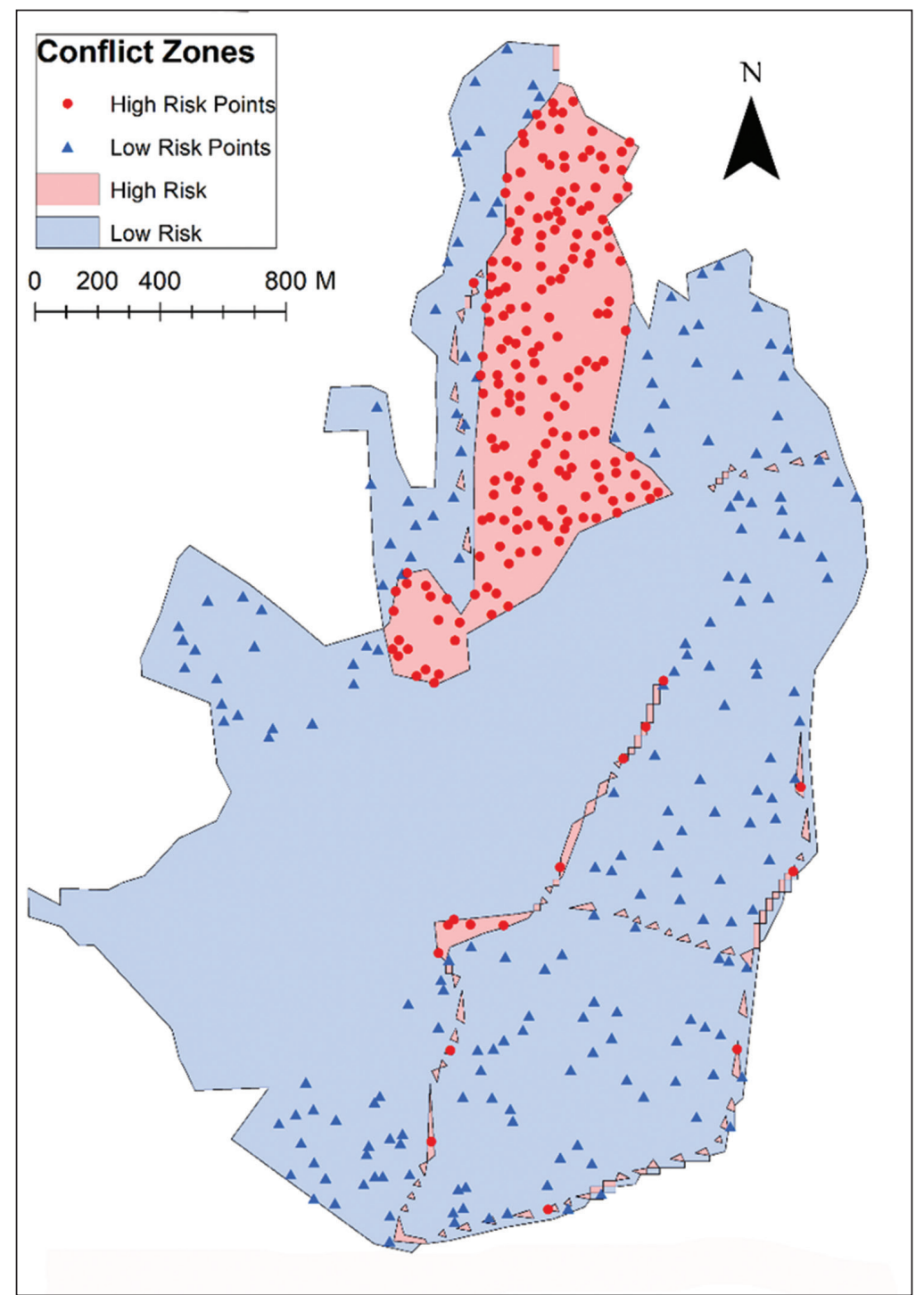

Figure 3. Map showing zones where human-deer (Cervus elaphus) encounters have occurred. Locations of randomly sampled points are shown as red dots (high risk points) and blue triangles (low risk points). Data collected from Lyme Park, Disley, UK, in 2018.

\section{Mapping encou Inter probability}

To determine how landscape features influenced the probability of human-deer encounters, a binary logistic regression model was built using the data provided by the distance matrix as described by Miller et al. (2016). Low and high-encounter points were used as the binary responses (Fig. 3). The feature predictor variables used in the model are shown in Table 1. The 'Not surveyed' and 'Swamp, Marginal and Inundation' features covered only a small area in the two herd ranges $(>0.01 \%)$ and thus did not 
provide enough sample points to include them in any further analysis. Starting with a global model, ranked models were generated using all combinations of habitat variables (Table 2); this was carried out using the "gmulti" package in R (R Core team, 2013. R Version 3.5.1, www.r-project.org, Accessed 12 Dec 2019)

Akaike's Information Criterion (AIC) was used to select the best fit model. As the highest scoring model did not reach an Akaike weight $>0.90$, the top 8 models (Table 3) were averaged to produce the final model. The sum of the AIC scores also allowed a comparison between the contribution of each habitat variable to the best fit model using relative importance. Relative importance ranged from 0 to 1 , with 1 indicating that the variable made a strong contribution to the model.

Table I. Predictor variables used in the study. Showing evidence of importance in relation to humanungulate encounters.

\begin{tabular}{|c|c|c|}
\hline Category & Predictor variable - landscape feature (unit) & Evidence of effect on encounter probability \\
\hline \multirow[t]{2}{*}{ Human Presence } & Distance to buildings/gardens/visitor centres (m) & Increased human activity stresses deer. ${ }^{\text {ab,c,c,d }}$ \\
\hline & Distance to recreational routes (roads/paths) (m) & \\
\hline \multirow[t]{7}{*}{ Land Use } & Distance to woodland/scrub (m) & Provide refuge space ${ }^{\mathrm{c}, e}$ and effects vigilance levels of deer. ${ }^{\mathrm{f}}$ \\
\hline & Distance to grassland/marsh $(\mathrm{m})$ & Human disturbance can affect foraging. ${ }^{c}$ alongside other \\
\hline & Distance to heathland (m) & deer habitat uses. ${ }^{f}$ \\
\hline & Distance to mire (m) & \\
\hline & Distance to tall herb/fern (m) & \\
\hline & Distance to running water $(\mathrm{m})$ & Drinking requires the entry to high risk areas, \\
\hline & Distance to open water $(\mathrm{m})$ & prioritised over vigilance. ${ }^{g}$ \\
\hline
\end{tabular}

Table 2. Landscape features in Lyme Park and their relative percentage covered and area, separated for the Park and Moore deer herd.

\begin{tabular}{lcccc}
\hline \multirow{1}{*}{ Landscape feature } & \multicolumn{2}{c}{ Area (hectares) } & \multicolumn{2}{c}{ Area (\%) } \\
\cline { 2 - 5 } & Moor & Park & Moor & Park \\
\hline Building/Garden/Visitor centre & 0,52 & 1,47 & 0,28 & 0,67 \\
Footpath/Road & 8,28 & 23,81 & 4,43 & 10,87 \\
Grassland/Marsh & 146,38 & 146,42 & 78,28 & 66,86 \\
Heathland & 0 & 1,27 & 0 & 0,58 \\
Mire & 2,23 & 2,93 & 1,19 & 1,34 \\
Open water & 0 & 0,83 & 0 & 0,38 \\
Running water & 2,56 & 0,7 & 1,37 & 0,32 \\
Tall herb/Fern & 11,93 & 0,35 & 6,38 & 0,16 \\
Woodland/Scrub & 15,09 & 41,22 & 8,07 & 18,82 \\
\hline
\end{tabular}

Table 3. Explanatory variables which were included in each of the top 8 models produced. All explanatory variables were included in the final average model.

\begin{tabular}{|c|c|c|c|c|c|c|c|c|c|}
\hline Explanatory variable & Model 1 & Model 2 & Model 3 & Model 4 & Model 5 & Model 6 & Model 7 & Model 8 & Average \\
\hline Build./Gard./Visitors centre & $\checkmark$ & $\checkmark$ & $\checkmark$ & $\checkmark$ & $\checkmark$ & $\checkmark$ & $\checkmark$ & $\bar{\checkmark}$ & $\checkmark$ \\
\hline Footpath/Road & $\checkmark$ & $\checkmark$ & & & $\checkmark$ & $\checkmark$ & & & $\checkmark$ \\
\hline Grassland/Marsh & $\checkmark$ & $\checkmark$ & $\checkmark$ & $\checkmark$ & & & & & $\checkmark$ \\
\hline Heathland & $\checkmark$ & $\checkmark$ & $\checkmark$ & $\checkmark$ & $\checkmark$ & $\checkmark$ & $\checkmark$ & $\checkmark$ & $\checkmark$ \\
\hline Mire & $\checkmark$ & & $\checkmark$ & & $\checkmark$ & & $\checkmark$ & & $\checkmark$ \\
\hline Open water & $\checkmark$ & $\checkmark$ & $\checkmark$ & $\checkmark$ & $\checkmark$ & $\checkmark$ & $\checkmark$ & $\checkmark$ & $\checkmark$ \\
\hline Running water & $\checkmark$ & $\checkmark$ & $\checkmark$ & $\checkmark$ & $\checkmark$ & $\checkmark$ & $\checkmark$ & $\checkmark$ & $\checkmark$ \\
\hline Tall herb/Fern & $\checkmark$ & $\checkmark$ & $\checkmark$ & $\checkmark$ & $\checkmark$ & $\checkmark$ & $\checkmark$ & $\checkmark$ & $\checkmark$ \\
\hline Woodland/Scrub & $\checkmark$ & $\checkmark$ & $\checkmark$ & $\checkmark$ & $\checkmark$ & $\checkmark$ & $\checkmark$ & $\checkmark$ & $\checkmark$ \\
\hline
\end{tabular}


The relationship of each predictor variable to the encounter probability was examined by holding all variables constant at their mean. To measure the performance of this binary classifier, a receiver operating characteristic (ROC) curve was generated by plotting the true positive rate (TPR) against the false positive rate (FPR) at various threshold settings. The area under the curve (AUC) was then calculated to assess the model performance. The probability data of deer-human encounters was then mapped for each $20 \times 20 \mathrm{~m}$ grid using ArcGIS. Encounter risk ranged from 0 to 1 and was divided into five categories $(0-0.19,0.2-0.39,0.4-0.59,0.6-0.79,0.8-1)$ for mapping purposes.

\section{Determining high and low visitor days}

The relative proportion of visitors on each day of the week was retrieved from Google Visitor Data which uses aggregated and anonymised data from users who have opted in to Google Location History. This data was used to calculate the percentage of visitors a day visiting the park: Wednesdays and Thursdays were identified to be days of low visitor numbers (5-8\% of total weekly visitors) and Saturdays and Sundays of high visitor numbers (21-27\% of total weekly visitors) (Table 4).

\section{Sample collection}

Fresh faecal samples were collected in Lyme Park between June and August 2018. Samples were determined to be fresh primarily based on direct observation of defecation events; in cases where the event was not witnessed, pellets in the area immediately vacated by the deer were assessed for freshness based on three metrics; level of moistness, pellet being intact, and resting atop ground flora (Goode et al. 2014). Only samples which matched all three metrics were collected. To compare cortisol levels between the Park and Moor herd, we collected ten faecal samples from each herd, every day over a seven-day period: 25 Jun 2018-1 July $2018(\mathrm{n}=140)$. To compare deer cortisol levels between days that experienced low and high number of visitors (Table 4) 20 additional samples were collected four times a week on the days following the expected highest and lowest visitor numbers (Thursday, Friday, Sunday and Monday). This comparison was only done between individual days. This second set of samples was only collected from the Park herd over the period 5 July 2018-6 August $2018(\mathrm{n}=400)$. These samples were collected between $5 \mathrm{am}$ and $7 \mathrm{am}, 18$ hours after peak visitor hours; a

Table 4. Weekly number of visitors (\%) in the summer who visit Lyme Park. Values are based on relative numbers of visitors extracted from Google analytics (see methodology for further detail).

\begin{tabular}{lcc}
\hline & Day & Weekly number of visitors (\%) \\
\hline Monday & 16 \\
Tuesday & 10 \\
Wednesday & 5 \\
Thursday & 8 \\
Friday & 13 \\
Saturday & 21 \\
Sunday & 27 \\
\hline
\end{tabular}


timeframe that has been shown to fall within the gut passage time of cortisol in deer (Millspaugh et al. 2002).

In order to reduce the effect of different metabolic rates between individual animals, samples were collected over a short time frame each day and homogenised when processed in the laboratory (Goymann 2012). The time of the year and the duration of the collection of the samples (June-August), fell before the rut and before the females came into esterus. This limited the impact the sex of the deer, and the reproductive state of females, would have over the short six-week period (Gordon 1997; Huber et al. 2003). To further limit these possible impacts, we avoided the collection of samples from male deer who tended to isolate themselves from the main group and from female deer with foals. The fresh samples were stored following standard protocol at $-20^{\circ} \mathrm{C}$, to prevent further metabolisation, until the extraction and assay analysis were conducted (Touma and Palme 2005; Konjević et al. 2011; Pavitt et al. 2016).

\section{Hormone extraction and assay analysis}

We used the DetectX Steroid Immunoassay Kit from Arbor Assays for the cortisol analysis (catalogue \#K003-H5). This kit was validated for dried faecal extracts by the manufacturer and had been used to measure cortisol in a number of previous studies (Brand et al. 2016; Chen et al. 2017; Endo et al. 2018). The hormone extraction and assay analysis followed the manufacturer's guidelines (Arbor Assays 2009) with 2 alterations: all samples were processed wet and methanol was used in place of ethanol during the extraction procedure. These changes were based on the recommendations of a steroid extraction review (Palme 2012).

All samples were defrosted and all samples from a single day were homogenised. Two $0.5 \mathrm{~g}$ amounts of wet homogenised sample were weighed out (treated as replicates for each weekday). We added $5 \mathrm{~mL}$ of $90 \%(\mathrm{v} / \mathrm{v})$ methanol and incubated the samples at room temperature on an orbital shaker overnight. To remove any insoluble material the samples were centrifuged at $500 \mathrm{~g}$ for 20 minutes; solvents were removed from the supernatant in a SpeedVac at $60{ }^{\circ} \mathrm{C}$ until dry. All the dried homogenised pellets from each day were resuspended in a total volume of $500 \mu \mathrm{L} 90 \%(\mathrm{v} / \mathrm{v})$ methanol.

Resuspended samples were diluted in assay buffer at a 1:20 ratio. $50 \mu \mathrm{L}$ of samples and standards were pipetted into the relevant wells; $75 \mu \mathrm{L}$ of assay buffer were pipetted into each of the non-specific binding (NSB) wells. $50 \mu \mathrm{L}$ of assay buffer was pipetted into the maximum binding (B0) wells. $25 \mu \mathrm{L}$ of cortisol conjugate was added to each well, followed by $25 \mu \mathrm{L}$ of cortisol antibody to each well (except the NSB wells). The plate was covered with a plate sealer and rotated on an orbital shaker at room temperature for 1 hour. The wells were aspirated before being washed four times with $300 \mu \mathrm{L}$ wash buffer. $100 \mu \mathrm{L}$ of the TMB Substrate was added to each well and the plates were incubated at room temperature for 30 minutes. $50 \mu \mathrm{L}$ of the stop solution was added to each well. The optical density generated from each well was read using an ASYS UVM340 plate reader at $450 \mathrm{~nm}$. Cortisol concentrations were determined from these readings using the manufacturers' online data analysis tool (MyAssays Ltd., https://www.myassays. com/arbor-assays-detectx-cortisol (extended-range) assay, Accessed 12 Dec 2019). 


\section{Statistical analysis of the cortisol levels}

To test for data normality a Shapiro-Wilk test was used. To test homogeneity a Bartlett test was used. A t-test was used to test for difference in cortisol levels between the two herds. A Kruskal Wallis test was used to test for differences between visitor days. Significance threshold was set at $\mathrm{p}=0.05$. All statistical analysis was carried out in R (2013).

\section{Results}

\section{Model validation and feature probability}

The power and accuracy of the best fit model (Table 5) to predict the probability of an encounter occurring within a grid square, based on landscape features, was validated using a ROC curve (Fig. 4). The high AUC (AUC = 0.92) suggests that the model had

Table 5. Results from best fit model. All explanatory variables were included in this model.

\begin{tabular}{lccc}
\hline \multicolumn{1}{c}{ Feature } & Estimate & Standard Error & t Value \\
\hline (Intercept) & $7.49 \times 10-1$ & $2.4 \times 10-2$ & $31.194^{* *}$ \\
Building/Garden/Visitors centre & $1.44 \times 10-4$ & $8.35 \times 10-6$ & $-17.292^{* *}$ \\
Footpath/Road & $-2.91 \times 10-5$ & $5.24 \times 10-6$ & $-5.546^{* *}$ \\
Grassland/Marsh & $2.98 \times 10-5$ & $4.87 \times 10-6$ & $6.118^{* *}$ \\
Heathland & $2.21 \times 10-4$ & $4.09 \times 10-6$ & $-53.91^{* *}$ \\
Mire & $-1.06 \times 10-5$ & $4.93 \times 10-6$ & $-2.153^{*}$ \\
Open water & $-1.52 \times 10-4$ & $7.62 \times 10-6$ & $-19.992^{* *}$ \\
Running water & $1.59 \times 10-4$ & $5.12 \times 10-6$ & $31.044^{* *}$ \\
Tall Herb/Fern & $1.28 \times 10-4$ & $5.67 \times 10-6$ & $22.656^{* *}$ \\
Woodland/Scrub & $-6.97 \times 10-5$ & $5.88 \times 10-6$ & $-11.839^{* *}$ \\
\hline
\end{tabular}

*Significant at $\mathrm{p}<0.05{ }^{* *}$ Significant at $\mathrm{p}<0.05$

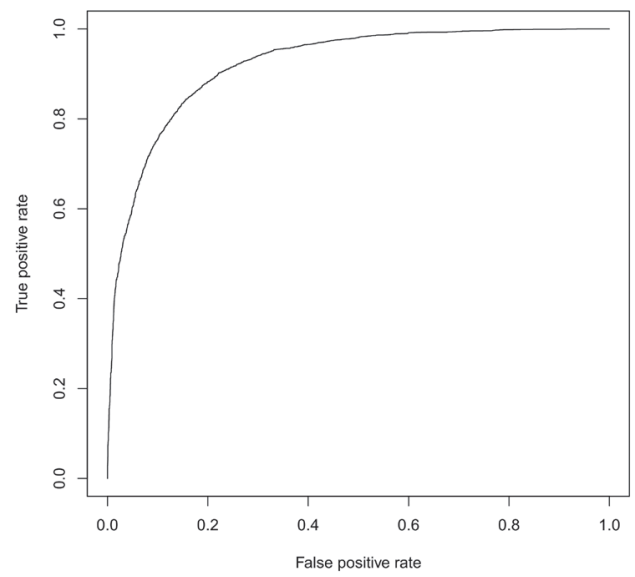

Figure 4. Receiver operating characteristic (ROC) curve showing the predictability of the human-deer (Cervus elaphus) encounter model. The true positive rate (sensitivity) is plotted as a function of the false positive rate (specificity). The area under the ROC curve was 0.92. Data collected from Lyme Park, Disley, UK, in 2018. 
(A) BuilingygardenNvistor Cente

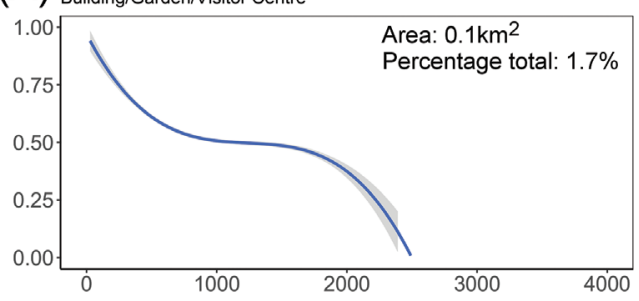

(B) Footpath/Road

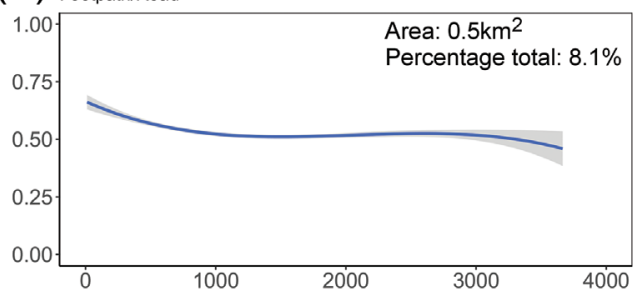

$\geqslant(\mathrm{C})_{\text {Grassland/Marsh }}$

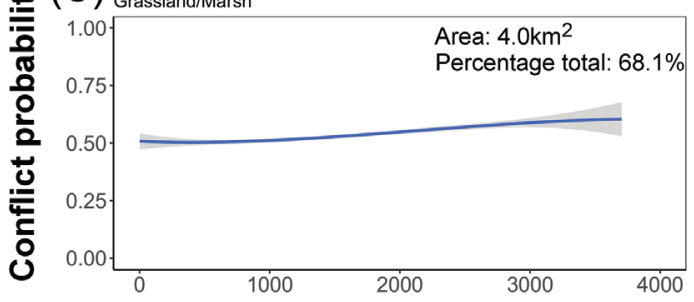

(D) Heathend

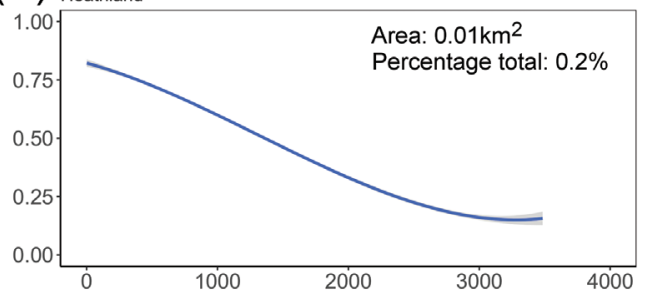

$(E)$ Mire

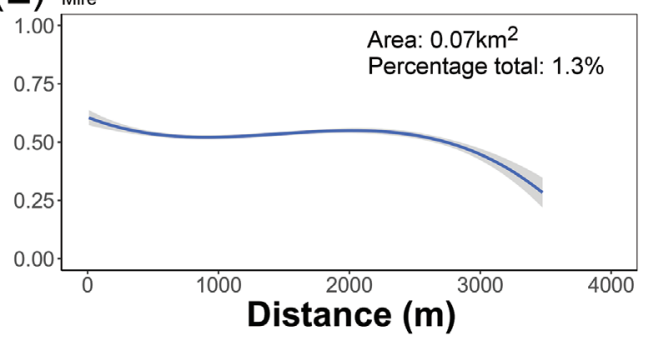

(K)

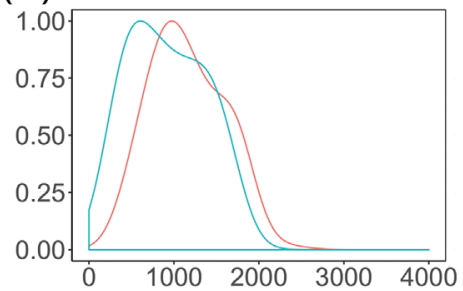

$(\mathrm{L})$

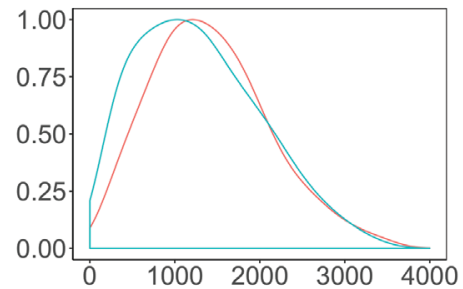

(M)

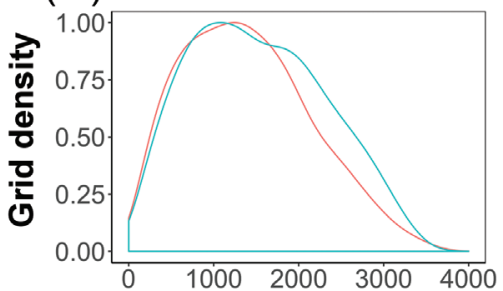

(N)

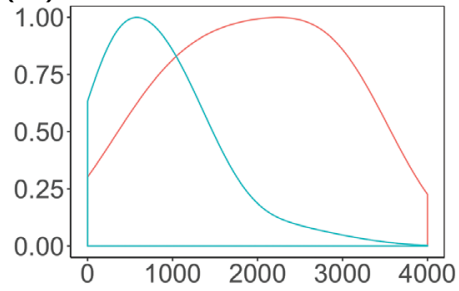

(O)

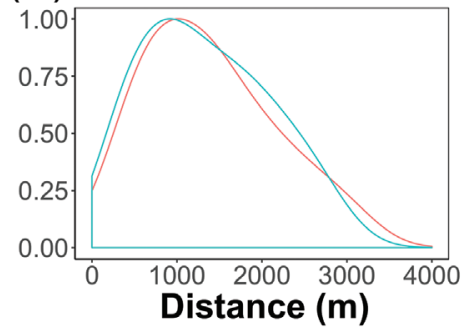

Figure 5I. A-E human-deer (Cervus elaphus) encounter probability modelled with distance to each feature. The $95 \%$ confidence intervals are shown in grey $\mathbf{K}-\mathbf{O}$ Density distribution of randomly sampled high-encounter points (blue) and low-encounter points (red) modelled with distance to each feature. Data collected from Lyme Park, Disley, UK, in 2018. 
(F) Open Water

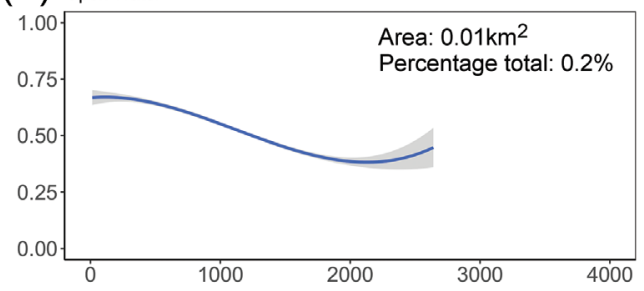

(G) Running Water

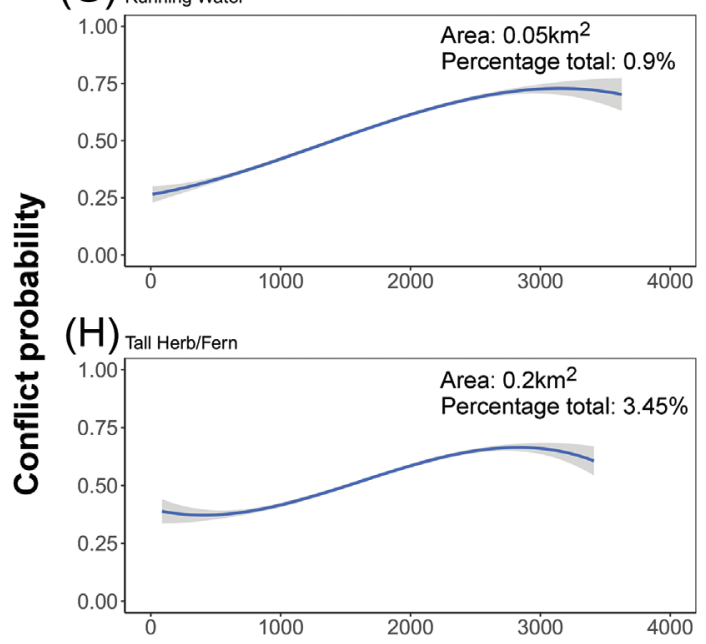

(I) Woodland/Scrub

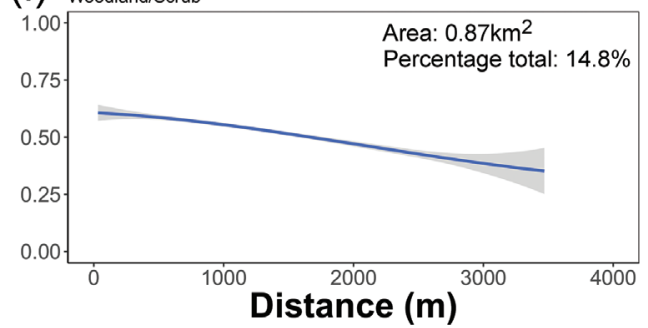

(P)

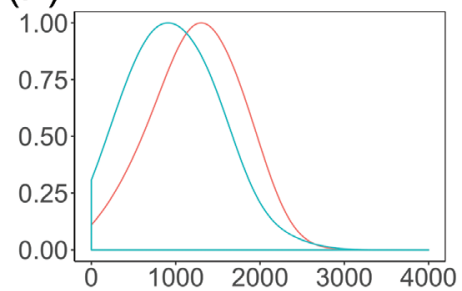

(Q)

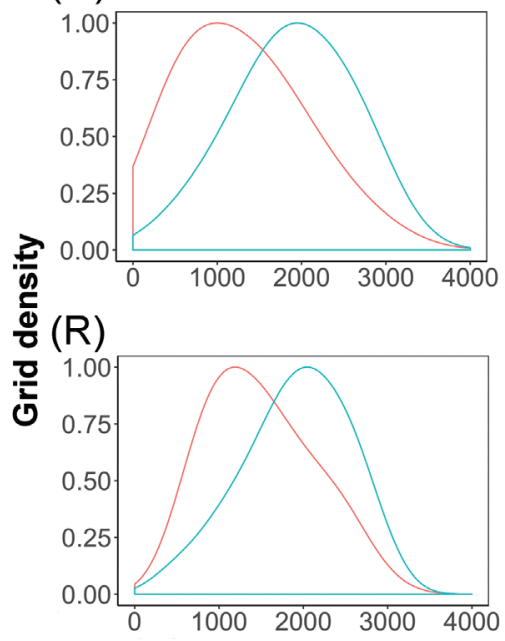

(S)

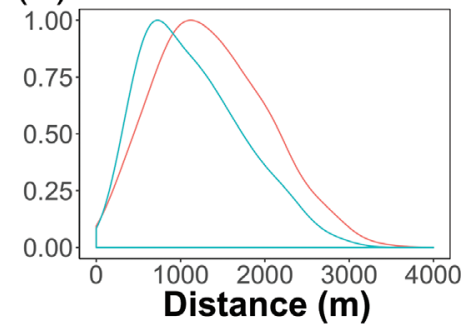

Figure $\mathbf{5} \mathbf{I}$ I. Continued. F-I human-deer (Cervus elaphus) probability modelled with distance to each feature. The $95 \%$ confidence intervals are shown in grey P-S Density distribution of randomly sampled high-encounter points (blue) and low-encounter points (red) modelled with distance to each feature. Data collected from Lyme Park, Disley, UK, in 2018.

a good predictability (Robertson et al. 1983; Swets 1988). For each modelled landscape feature, the encounter risk probability was plotted in relation to geographical distance. Running water, grassland/marsh, and tall herb/fern exhibited a positive correlation between encounter probability and increased distance. Building/garden/visitor centre, footpath/road, heathland, mire, open water and woodland/scrub exhibited a negative correlation between encounter probability and increased distance. Encounter probability was highest close to Building/Garden/Visitor Centre landscape features (Fig. 5). 


\section{Encounter heatmap}

The encounter heatmap takes the results of the model and applies them to create a visualisation of the spatial distribution of encounter probability (Fig. 6). The map shows high-encounter probabilities were predicted in the central areas of the park, generally aligning with areas where high visitor activity has been observed, most notably around the main visitor attraction of the house and lake. Low probability of encounter was predicted in areas of predominately Grassland/Marsh which were not close to other landscape features. The south of the park had the greatest proportion of low-encounter area. Five percent $\left(0.29 \mathrm{~km}^{2}\right)$ of Lyme Park fell into the highest risk category $(0.8-1)$, with a mean encounter probability across the park of 0.55 (Fig. 7).

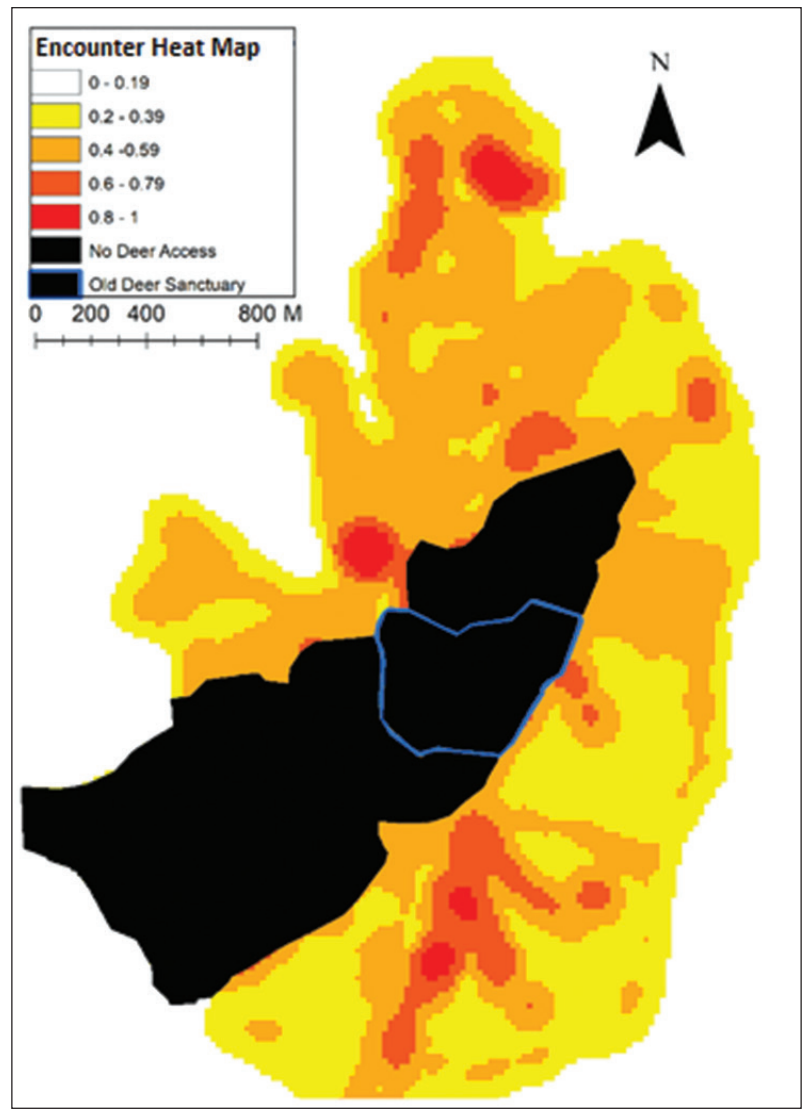

Figure 6. Modelled probability of human-deer (Cervus elaphus) encounters based on landscape features. Spatial grain $=20 \mathrm{~m}$. The darker the colour, the greater the probability of encounters occurring. The hatched area is currently not accessible by deer but was included for the mapping of the spatial model. Area outlined in blue is an old deer refuge area that may be reopened in future. Data collected from Lyme Park, Disley, UK, in 2018. 


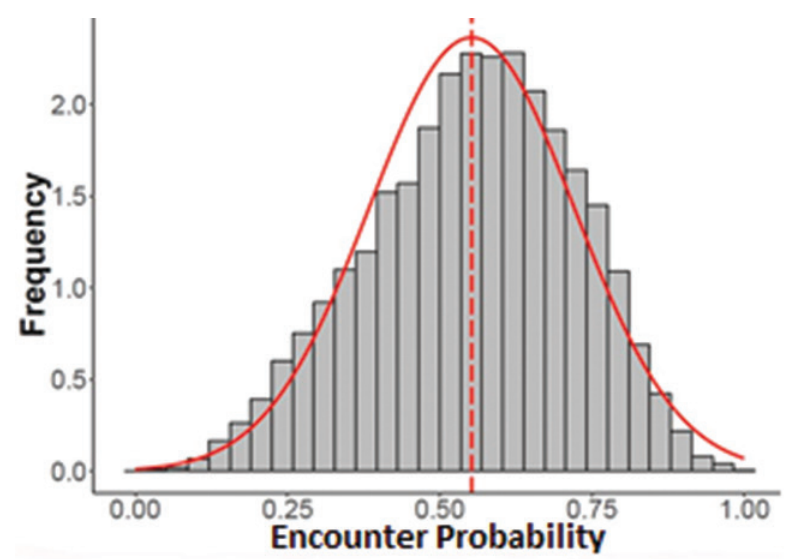

Figure 7. Frequency histogram showing encounter probability for all spatial grains $(n=66,902)$. The $y$-axis is a proportional scale $(2=3000)$. Data collected from Lyme Park, Disley, UK, in 2018.

\section{Faecal cortisol}

The assay results showed that cortisol levels differed significantly between the herds $(\mathrm{t}$ $=2.27, \mathrm{df}=26, \mathrm{P}=0.03)$, with the Moor Herd $(\mathrm{M}=8329.14, \mathrm{SD}=4142.2)$ being significantly higher than the Park Herd $(M=5135.29, S D=3266.05)$. The cortisol levels were only found to be significantly higher on Sundays compared to Wednesdays; comparisons between the other days found no significant differences (Fig. 8).

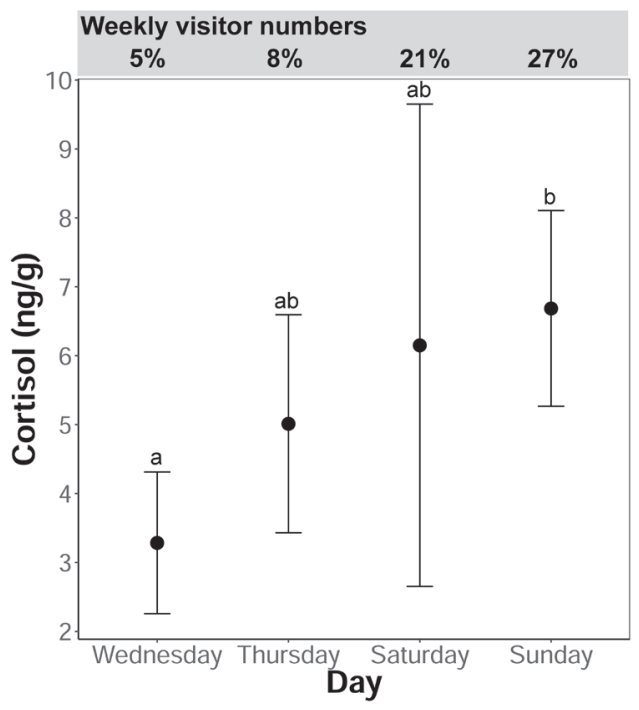

Figure 8. Mean faecal cortisol concentrations and $95 \%$ confidence interval from samples collected at different days of the week. Different letters indicate significant differences at $\mathrm{p}=0.05$. The grey box above the figure shows the weekly percentage (of the total) visitor numbers during the period when the samples were collected. Data collected from Lyme Park, Disley, UK, in 2018. 


\section{Discussion}

The study found a link between the numbers of visitors in the park and the amount of cortisol found in the faecal matter of the deer. This was a notable finding for the rangers at the site who could use these results to strengthen the argument that visitors are indeed having an impact on the wellbeing of the herd. The impact of human activity in green spaces is an issue that is likely to increase in the future, as the pressure on British green spaces will grow with an increase in population. Our encounter probability map can become a useful tool for rangers to inform their management practices on the ground. Although the map presented here used Lyme Park as a study system, the methodology used can be applied by other, different sites, or species of conservation/malmanagement concern, in order to better understand encounter probability between humans and wildlife.

Previous studies used several different methods to measure deer stress levels, including blood sampling (Jones and Price 1992; Huber et al. 2017), hair sampling (Caslini et al. 2016) and clinical assessments (Montane et al. 2002). A non-invasive technique, which did not require the capture of the deer, was prioritised for this study. The measurement of cortisol levels in faecal samples provided an insight into deer stress levels whilst avoiding additional stress from the collection of this data. This method had been used successfully by several other studies (Millspaugh et al. 2002; Jayakody et al. 2011; Landry et al. 2016; Zbyryt et al. 2018).

The mean cortisol levels of the herd were related to the percentage of weekly visitors to the park on each of the days. Post Hoc, pairwise comparisons using the Tukey and Kramer (Nemenyi) test with Tukey-Dist approximation for independent samples indicated that the cortisol levels were only found to be significantly higher on Sundays compared to Wednesdays; comparisons between the other days found no significant differences (Fig. 8). The large error bars displayed for the combined Saturday reading were due to this day containing the largest variance in result values. This could potentially be explained by either abnormal stress events affecting the deer on individual Saturdays, or by fluctuations in visitor numbers due to external factors. Lyme Park is free of large predators, leaving humans (and their dogs) as the primary predator-related stress factor for the deer. Zbyryt et al. (2018) also showed in their work that proximity to humans increased the frequency of stressful events and, as a result, the intensity of the animals' hormonal response also increased.

In addition, faecal cortisol levels were also compared between the two herds present in the park. The result was unanticipated as we found the moor herd, which is exposed to fewer visitors, was found to have significantly higher cortisol levels compared to the park herd and was located in the area with the lower probability of encounter.

Habituation is a possible explanatory factor for why cortisol levels in the park herd were lower. Repeated exposure to the stressor is a requirement for habituation to occur (Romero 2004). As the Park Herd is exposed to many visitors moving within their range every day, they are likely to have acclimated to visitor presence to a greater degree compared to the Moor herd. This acclimatisation may result in the park herd avoiding 
areas of high disturbance, which they can recognise through repeated exposure. This type of avoidance behaviour has been highlighted as a result of habituation occurring (Bonnot et al. 2013).

In the case of Lyme Park these high disturbance areas may be the areas surrounding the gates and the car parks which are extremely busy. The possibility that the park herd has habituated to the visitors may have mitigated the stress response but it has not been eliminated completely, hence this is why the busier visitor days still had an impact on them. During the study the deer were observed being extremely wary of humans and would flee if approached, suggesting that the herd has not been completely habituated. As the moor herd was not subjected to the same level of visitor numbers with the same regularity and predictability, they may not have developed the same avoidance strategies as the park herd, meaning less mitigation of their stress response.

A second explanatory factor may be the differences in habitat types found in each of the herd's ranges. The map generated allows for the visualisation of how each landscape feature interacts across the spatial frame of Lyme Park. This allows the role of habitat to be examined in greater depth. The main feature which was comparatively sparse in the moor herds range was woodland and scrub. Studies have indicated this type of landscape provides refuge areas where ungulates can avoid stressors, particularly predators (Torres et al. 2012). As humans are perceived by deer as potential predators, tree cover could be utilised in much the same way (Ciuti et al. 2012). This refuge-seeking response to human activity has been found to be most prevalent during summer days (Coppes et al. 2017a) during a similar time when we collected our data. The increased need to maintain constant vigilance is a behaviour intrinsically linked to disturbance and has been correlated with decreasing time spent feeding and increased stress levels (Torres et al. 2012). The effects of lacking refuge could be exacerbated by the weather such as wind and precipitation in the winter, and as shelter from the heat and sun in summer. Exposure to these types of weather conditions due to a lack of cover has been found to result in higher cortisol levels in ungulates (Landry et al. 2016). Whilst this possibility has been supported by the aforementioned papers, it is important to note that the quantification of vegetation cover was not carried out as part of this study. Doing so could offer a greater insight into the suitability of the habitats at Lyme Park to act as sufficient cover.

The importance of the woodland/scrub landscape feature as a refuge can also be looked at across the entirety of the park. Our model found that the closer a point was to woodland/scrub, the lower the expected encounter probability was. This again supports its utilisation by deer as a refuge in areas where human activity is prevalent (Ciuti et al. 2012; Torres et al. 2012; Coppes et al. 2017a). Red deer in less forested sites have also been found to exhibit a stronger reaction to disturbance than those in more densely forested sites (Jarnemo and Wikenros 2014). The current management at Lyme Park reflects this thinking: a section of woodland within the park herd range is closed to the public, providing a refuge area for the herd. A similar refuge area is not present in the moor herds' range: this offers an opportunity for management to be altered to reduce the probability of human-deer encounters. 
Opening the old deer sanctuary area (Fig. 6), would likely be a good option. This area is wooded, a feature which is currently lacking in the Moor Herds' range. It would be preferable to restrict human access to this area. If this is not possible it could be considered only for peak visiting hours. This would provide additional refuge area for the deer, as well as providing a buffer between the busier central area of the park and the rest of the herds' range.

To try to reduce deer cortisol levels across the entire park the map and model we produced is useful as it outlined the relationship between encounter probability and the distance to individual landscape features (Figs 5, 6). As human presence is a required factor for human deer encounters to occur, it is not surprising that the areas in the park which attract many of the visitors increase the probability of humans and deer encounters. This is especially true in the case of Lyme Park, where the deer are considered a visitor attraction and as a result are actively sought out by some visitors. An example of an area where visitors were abundant and encounter risk was high is the main house, gardens, and particularly the lake. Open water is an essential habitat resource, which has been found to be a strong driver for habitat selection by deer (Wu et al. 2016; Coppes et al. 2017a). Our model predicted that the closer to open water a point was, the higher the encounter probability. The map also shows this relationship with the lake falling into a red, high encounter probability zone (Fig. 6). The lake is a popular destination for visitors due to its location beside the café. It is also popular with deer whenever there are no visitors in the park, e.g. early morning. Despite running water similarly being an essential habitat resource it exhibits the opposite relationship; this is likely because it falls outside of the high visitor areas. Providing alternate open water accessible to the deer but not to visitors may help reduce deer stress levels.

Similarly, low-encounter areas can also be useful as they can provide a template for low stress deer habitat which can then be emulated in other areas of the park, particularly in identifying areas that can improve alternate areas of deer refuges (Torres et al. 2012; Coppes et al. 2017a). Not all landscape features showed a clear relationship between distance and encounter probability: the most notable example is the grassland/marsh feature. This covered the largest habitat area in both the high and low risk zones (Table 2). The encounter probability remained relatively stable as risk points from either encounter zones are generally near to this feature. At the greatest distances encounter probability increased as the confidence intervals widened (Fig. 8).

\section{Conclusion and management implications}

Finding ways to reduce the probability of human-deer encounters is an important consideration for the management of this site, and, by extension, other similar sites. The site managers want to reduce the stress responses these encounters cause, as it has the potential to impair biological functions and lower survival rates of their deer populations (Sapolsky et al. 2000). The impact the visitors are having on deer stress levels is 
an inherent problem due to the nature of the site. Restricting visitor access to larger areas of the park where the herds are primarily situated would also greatly reduce the risk of human-deer encounters. However, this would need to be balanced against the loss of potential visitors and the funds they bring. A more realistic aim which would keep the majority of the park open, whilst giving the deer relief from human activity would be to mitigate the risk of human-deer encounters occurring specifically close to deer refuge areas. This mitigation of deer stress could be further supported through the creation of more deer refuge areas, particularly the old deer sanctuary in moor herds' range; the creation of alternate open water sources away from high visitor areas and the emulation of low encounter habitat in other higher risk areas of the park.

The methods used in this study could be adapted and transferred to inform local conservation management elsewhere. The results of our cortisol experiment support other studies which found that human disturbance can negatively impact deer stress levels. This alone should give reason for managers at sites which contain deer to consider the impact visitor numbers may be having on their herds. As the visitor pressure increases across British greenspaces this is likely to become a more prevalent problem. Although some of these negative effects may be reduced by increased habituation of the deer to visitors, this paper has shown that even herds exposed to human activity over a period of decades still exhibit an increase in cortisol levels on days when visitor numbers are highest. The mapping and modelling systems used in this paper could readily be adapted for other sites to help modify deer management to help limit the impact of human disturbance. The model and map would allow for the identification of high encounter zones which would require mitigated or low encounter zones to be promoted. Although the management recommendations are linked to the unique landscape of Lyme Park, they are rooted in the findings of other papers, making them generally applicable. In particular, the importance of refuge areas is something managers should not overlook as it is a valuable resource highlighted in our own paper and supported by other studies.

\section{Acknowledgements}

This collaboration came about through the Knowledge Transfer Partnership, initiated by the University of Manchester and the National Trust. We thank the National Trust for giving us site access and collection permits for Lyme Park and the Biology Department at Edge Hill University for their financial and facility support. Specifically, we would like to thank B. Wilcock for his support during this project.

\section{Compliance with ethical standards}

All applicable international, national, and/or institutional guidelines for the care and use of animals were followed. 


\section{References}

ArcGIS (2011) Environmental Systems Research Institute, Inc., Redlands, CA, USA

Arbor Assays (2009) Arbor Assays, Ann Arbor, MI, USA, https://www.arborassays.com/documentation/inserts/K003-H.pdf [Accessed 12 Dec 2019]

Bonnot NC, Morellet N, Verheyden H, Cargnelutti B, Lourtet B, Klein F, Hewison AJM (2013) Habitat use under predation risk: Hunting, roads and human dwellings influence the spatial behaviour of roe deer. European Journal of Wildlife Research 59(2): 185-193. https://doi.org/10.1007/s10344-012-0665-8

Brand CM, Boose KJ, Squires EC, Marchant LF, White FJ, Meinelt A, Snodgrass JJ (2016) Hair plucking, stress, and urinary cortisol among captive bonobos (Pan paniscus). Zoo Biology 35(5): 415-422. https://doi.org/10.1002/zoo.21320

Bratman GN, Hamilton JP, Hahn KS, Daily GC, Gross JJ (2015) Nature reduces rumination and sgPFC activation. Proceedings of the National Academy of Sciences of the United States of America 112(28): 8567-8572. https://doi.org/10.1073/pnas.1510459112

British Deer Society (2018) BDS Captive Deer Survey. https://www.bds.org.uk/index.php/ documents/233-bds-captive-deer-survey-public-sites-forbds-website-as-at-10-may-18 [Accessed 12 Dec 2019]

Broom DM (1991) Animal welfare: Concepts and measurement. Journal of Animal Science 69(10): 4167-4175. https://doi.org/10.2527/1991.69104167x

Caslini C, Comin A, Peric T, Prandi A, Pedrotti L, Mattiello S (2016) Use of hair cortisol analysis for comparing population status in wild red deer (Cervus elaphus) living in areas with different characteristics. European Journal of Wildlife Research 62: 713-723. https://doi. org/10.1007/s10344-016-1049-2

Chen H, Yao H, Yang W, Fan P, Xiang Z (2017) Assessing the utility of urinary and fecal cortisol as an indicator of stress in golden snub-nosed monkeys (Rhinopithecus Roxellana). PeerJ 5: e3648. https://doi.org/10.7717/peerj.3648

Cherry M, Morgan K, Rutledge B, Conner L, Warren R (2016) Can coyote predation risk induce reproduction suppression in white-tailed deer? Ecosphere 7(10). https://doi. org/10.1002/ecs2.1481

Ciuti S, Northrup JM, Muhly TB, Simi S, Musiani M, Pitt JA, Boyce MS (2012) Effects of humans on behaviour of wildlife exceed those of natural predators in a landscape of fear. PLoS One 7(11): e50611. https://doi.org/10.1371/journal.pone.0050611

Coppes J, Burghardt F, Hagen R, Suchant R, Braunisch V (2017a) Human recreation affects spatio-temporal habitat use patterns in red deer (Cervus elaphus). PLoS One 12(5): e0175134. https://doi.org/10.1371/journal.pone.0175134

Coppes J, Ehrlacher J, Thiel D, Suchant R, Braunisch V (2017b) Outdoor recreation causes effective habitat reduction in capercaillie Tetrao urogallus: A major threat for geographically restricted populations. Journal of Avian Biology 48(12): 1583-1594. https://doi. org/10.1111/jav.01239

Cox DTC, Shanahan DF, Hudson HL, Plummer KE, Siriwardena GM, Fuller RA, Anderson K, Hancock S, Gaston KJ (2017) Doses of neighborhood nature: The benefits for mental health of living with nature. Bioscience 67(2): 147-155. https://doi.org/10.1093/biosci/biw173 
D’Acunto LE, Spaul RJ, Heath JA, Zollner PA (2018) Simulating the success of trail closure strategies on reducing human disturbance to nesting Golden Eagles. The Condor 120(3): 703-718. https://doi.org/10.1650/CONDOR-17-223.1

DEFRA (2011) The natural choice: securing the value of nature. https:/www.gov.uk/government/ uploads/system/uploads/attachment_data/file/228842/8082.pdf [Accessed 12 Dec 2019]

Endo N, Yamane H, Rahayu LP, Tanaka T (2018) Effect of repeated adrenocorticotropic hormone administration on reproductive function and hair cortisol concentration during the estrous cycle in goats. General and Comparative Endocrinology 259: 207-212. https:// doi.org/10.1016/j.ygcen.2017.11.027

George SL, Crooks KR (2006) Recreation and large mammal activity in an urban nature reserve. Biological Conservation 133(1): 107-117. https://doi.org/10.1016/j.biocon.2006.05.024

Goode MJ, Beaver JT, Muller LI, Clark JD, van Manen FT, Harper CA, Basinger PS (2014) Capture-recapture of white-tailed deer using DNA from fecal pellet groups. Wildlife Biology 20(5): 270-278. https://doi.org/10.2981/wlb.00050

Gordon IR (1997) Controlled reproduction in horses, deer, and camelids. CABI, New York, New York, USA.

Goymann W (2012) On the use of non-invasive hormone research in uncontrolled, natural environments: The problem with sex, diet, metabolic rate and the individual. Methods in Ecology and Evolution 3(4): 757-765. https://doi.org/10.1111/j.2041-210X.2012.00203.x

Haigh A, Butler F, O’Riordan R, Palme R (2017) Managed parks as a refuge for the threatened red squirrel (Sciurus vulgaris) in light of human disturbance. Biological Conservation 211 : 29-36. https://doi.org/10.1016/j.biocon.2017.05.008

Hubbard RD, Nielson CK (2009) White-tailed deer attacking humans during the fawning season: a unique human-wildlife conflict on a university campus. Human-Wildlife Conflicts 3: 129-135. https://www.jstor.org/stable/24875694

Huber S, Palme R, Zenker W, Möstl E (2003) Non-invasive monitoring of the adrenocortical response in red deer. The Journal of Wildlife Management 67(2): 258-266. https://doi. org/10.2307/3802767

Huber N, Vetter GG, Evans AL, Kjellander P, Küker S, Bergvall UA, Arnemo JM (2017) Quantifying capture stress in free ranging European roe deer (Capreolus capreolus). BMC Veterinary Research 13(1): 127. https://doi.org/10.1186/s12917-017-1045-0

Jägerbrand AK, Alatalo JM (2015) Effects of human trampling on abundance and diversity of vascular plants, bryophytes and lichens in alpine heath vegetation, Northern Sweden. SpringerPlus 4(1): 95. https://doi.org/10.1186/s40064-015-0876-z

Jarnemo A, Wikenros C (2014) Movement pattern of red deer during drive hunts in Sweden. European Journal of Wildlife Research 60(1): 77-84. https://doi.org/10.1007/s10344013-0753-4

Jayakody S, Sibbald AM, Mayes RW, Hooper RJ, Gordon IJ, Lambin X (2011) Effects of human disturbance on the diet composition of wild red deer (Cervus elaphus). European Journal of Wildlife Research 57(4): 939-948. https://doi.org/10.1007/s10344-011-0508-z

Jones AR, Price SE (1992) Measuring the responses of fallow deer to disturbance. In: Brown RD (Ed.) The biology of deer. Springer, New York, 211-216. https://doi.org/10.1007/978-14612-2782-3_49 
Konjević D, Janicki Z, Slavica A, Severin K, Krapinec K, Božić F, Palme R (2011) Noninvasive monitoring of adrenocortical activity in free-ranging fallow deer (Dama dama L.). European Journal of Wildlife Research 57(1): 77-81. https://doi.org/10.1007/s10344-0100401-1

Landry DW, Metcalf C, Breuner W (2016) Recreational aviation and wildlife: The physiological stress response in deer and associated user perceptions. Intermountain Journal of Sciences 22(4).

Malavasi M, Santoro R, Cutini M, Acosta ATR, Carranza ML (2016) The impact of human pressure on landscape patterns and plant species richness in Mediterranean coastal dunes. Plant Biosystems 150(1): 73-82. https://doi.org/10.1080/11263504.2014.913730

Miller JRB, Jhala YV, Jena J (2016) Livestock losses and hotspots of attack from tigers and leopards in Kanha Tiger Reserve, Central India. Regional Environmental Change 16(1): 17-29. https://doi.org/10.1007/s10113-015-0871-5

Millspaugh JJ, Washburn BE, Milanick MA, Beringer J, Hansen LP, Meyer TM (2002) Noninvasive techniques for stress assessment in white-tailed deer. Wildlife Society Bulletin 30: 899-907. https://www.jstor.org/stable/3784245

Montane J, Marco I, Lopez-Olvera J, Manteca X, Lavin S (2002) Transport stress in roe deer (Capreolus capreolus): Effect of a short-acting antipsychotic. Animal Welfare (South Mimms, England) 11: 405-417.

MyAssays Ltd (2010) "Four Parameter Logistic Curve" online data analysis tool, MyAssays Ltd. https://www.myassays.com/how-to-reference-myassays.html [Accessed 12 Dec 2019]

National Trust (2018a) Busy days and planning your visit to Lyme. https://www.nationaltrust. org.uk/lyme/features/busy-days-at-lyme [Accessed 12 Dec 2019]

National Trust (2018b) Exciting times ahead - major improvements are coming to Lyme! https://www.nationaltrust.org.uk/lyme/features/exciting-times-ahead---major-improvementsto-lyme-are-coming [Accessed 12 Dec 2019]

National Trust (2018c) National trust open data: land - limited access. https://uknationaltrust. opendata.arcgis.com/datasets/f3cd21fd165e4e3498a83973bb5ba82f_0 [requires permissions, Accessed 12 Dec 2019]

Natural England (2011) monitor of engagement with the natural environment: The national survey on people and the natural environment. Annual Report from the 2009-2010 survey. http://publications.naturalengland.org.uk/file/72039 [Accessed 12 Dec 2019]

Natural England (2017) Monitor of engagement with the natural environment the national survey on people and the natural environment. Technical Report from the 2015-2016 survey. https://assets.publishing.service.gov.uk/government/uploads/system/uploads/attachment_data/file/612705/mene-technical-report-2015-16.pdf [Accessed 12 Dec 2019]

Palme R (2012) Monitoring stress hormone metabolites as a useful, non-invasive tool for welfare assessment in farm animals. Animal Welfare (South Mimms, England) 21(3): 331337. https://doi.org/10.7120/09627286.21.3.331

Pavitt AT, Pemberton JM, Kruuk LEB, Walling CA (2016) Testosterone and cortisol concentrations vary with reproductive status in wild female red deer. Ecology and Evolution 6(4): 1163-1172. https://doi.org/10.1002/ece3.1945 
R Core Team (2013) R: A language and environment for statistical computing. R Foundation for Statistical Computing, Vienna, Austria. http:/www.R-project.org/

Reilly ML, Tobler MW, Sonderegger DL, Beier P (2017) Spatial and temporal response of wildlife to recreational activities in the San Francisco Bay ecoregion. Biological Conservation 207: 117-126. https://doi.org/10.1016/j.biocon.2016.11.003

Reimoser S (2012) Influence of anthropogenic disturbances on activity, behaviour and heart rate or roe deer (Capreolus capreolus) and red deer (Cervus elaphus), in context of their daily and yearly patterns, Vienna. Nova Science Publishers.

Reyes-Martínez MJ, Ruíz-Delgado MC, Sánchez-Moyano JE, García-García FJ (2015) Response of intertidal sandy-beach macrofauna to human trampling: An urban vs. natural beach system approach. Marine Environmental Research 103: 36-45. https://doi. org/10.1016/j.marenvres.2014.11.005

Robertson EA, Zweig MH, Van Steirteghem AC (1983) Evaluating the clinical efficacy of laboratory tests. American Journal of Clinical Pathology 79(1): 78-86. https://doi. org/10.1093/ajcp/79.1.78

Romero LM (2004) Physiological stress in ecology: Lessons from biomedical research trends. Ecology and Evolution 19(5): 249-255. https://doi.org/10.1016/j.tree.2004.03.008

Sandifer PA, Sutton-Grier AE, Ward BP (2015) Exploring connections among nature, biodiversity, ecosystem services, and human health and well-being: Opportunities to enhance health and biodiversity conservation. Ecosystem Services 12: 1-15. https://doi. org/10.1016/j.ecoser.2014.12.007

Sapolsky RM, Romero LM, Munck AU (2000) How do glucocorticoids influence stress responses? Integrating permissive, suppressive, stimulatory, and preparative actions. Endocrine Reviews 21(1): 55-89. https://doi.org/10.1210/er.21.1.55

Scholten J, Moe SR, Stein RM, Hegland SJ (2018) Red deer (Cervus elaphus) avoid mountain biking trails. European Journal of Wildlife Research 64(1): 8. https://doi.org/10.1007/ s10344-018-1169-y

Shanahan DF, Bush R, Gaston KJ, Lin BB, Dean J, Barber E, Fuller RA (2016) Health benefits from nature experiences depend on dose. Scientific Reports 6: 28551. https://doi. org/10.1038/srep28551

Sibbald AM, Hooper RJ, McLeod JE, Gordon I (2011) Responses of red deer (Cervus elaphus) to regular disturbance by hill walkers. European Journal of Wildlife Research 57(4): 817-825. https://doi.org/10.1007/s10344-011-0493-2

Swets JA (1988) Measuring the Accuracy of Diagnostic Systems. Science 250(4857): 12851293. https://doi.org/10.1126/science.3287615

Thiel D, Jenni-Eiermann S, Braunisch V, Palme R, Jenni L (2008) Ski tourism affects habitat use and evokes a physiological stress response in capercaillie Tetrao urogallus: A new methodological approach. Journal of Applied Ecology 45(3): 845-853. https://doi. org/10.1111/j.1365-2664.2008.01465.x

Torres RT, Virgós E, Santos J, Linnell JDC, Fonseca C (2012) Habitat use by sympatric red and roe deer in a Mediterranean ecosystem. Animal Biology (Leiden, Netherlands) 62(3): 351-366. https://doi.org/10.1163/157075612X631213 
Touma C, Palme R (2005) Measuring fecal glucocorticoid metabolites in mammals and birds: the importance of validation. Annals of the New York Academy of Sciences 1046(1): 5474. https://doi.org/10.1196/annals.1343.006

Wu W, Li Y, Wu J (2016) Simulation of potential habitat overlap between red deer (Cervus elaphus) and roe deer (Capreolus capreolus) in northeastern China. PeerJ 4: e1756. https:// doi.org/10.7717/peerj.1756

Zbyryt A, Bubnicki JW, Kuijper DPJ, Dehnhard M, Churski M, Schmidt K (2018) Do wild ungulates experience higher stress with humans than with large carnivores? Behavioral Ecology 29(1): 19-30. https://doi.org/10.1093/beheco/arx142 